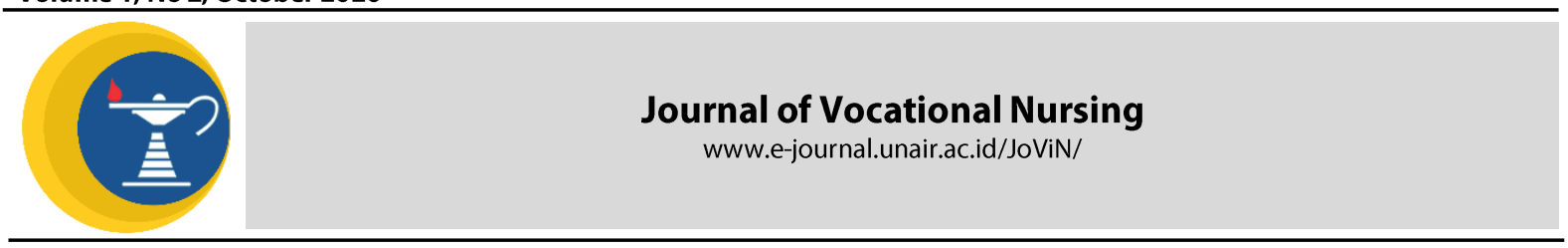

\title{
DETERMINANTS OF STUNTING IN CHILDREN AGED 24-59 MONTHS IN THE KASREMAN COMMUNITY HEALTH CENTER
}

Devi Kesumawati ${ }^{1}$ and Nurul Hidayah²

Research Report

${ }^{1,2}$ Akademi Keperawatan Pemkab Ngawi

\section{ABSTRACT}

Introduction: In Indonesia stunting still the main problem and concern in the field of nutrition, this condition in mark with height not according to age measured use the $z-$ score. Children said stunting if the $z-s c o r e<-2 S D$ until $\geq-3 S D$ and very short if $<-3 S D$. Methods: This study to attemps to analyze the determinant. Stunting using study correlation with case design study case control done measurements on past (retrospektif) 38 group with the total sample case and 38 respondents. Results: The control group thr kind of data used primary data. Respondents who experienced anemia is 20 and 15 respondents $(39,5 \%)$ have children stunting and 5 responden $(13,5$ $\%)$ has a normal, with $p$-value $p=0,019(p<0,005)$ showing there the relationship between the anemia as the stunting in the work area Puskesmas Kasreman Conclusion: The conclusion of research is several factors such in minutely in the work area Puskesmas Kasreman, risk heving the anemia higher have children stunting. Expected health service, parents and knowledge of the factor causing people to stunting to prevent the occurrence stunting.
ARTICLE INFO

Recived 20 October 2020

Accepted 26 October 2020

Online 29 October 2020

*Correspondence:

Devi Kesumawati

*Email:

heydevijaljinae@gmail.com

Keywords:

Determinant, Stunting, Age 24-59 Month

\section{INTRODUCTION}

Stunting is a chronic malnutrition condition characterized by the child's height not according to age, this is measured using the zscore, the child is said to be short if the $z$-score is $<-2$ SD to $\geq-3 S D$ and -3SD for the very short category (Divine, 2017). The impact of stunting can be in the form of hampered growth and development which will hinder the future of the child (Ministry of National Development Planning / Bappenas, 2018). According to the World Health Organization (WHO) 2018, the prevalence of stunting in children under five in 2017 was 151 million (22\%). Indonesia (36.4\%) is in the third position with the highest stunting children under five in Southeast Asia after Timor Leste (50.2\%) and India (38.4\%) (WHO, 2018). The results of Basic Health Research (RISKESDAS) regarding the highest prevalence of stunting and very short stunting occurred in the Southeast Asia region with a total of 15,510 people $(51.7 \%)$ in 2013 and decreased in 2018 to 12.870 people (42.6\%). In the East Java region, stunting has also decreased from 2013-2018, from 9,750 people (32.5\%) to 8,250 people (27.5\%) (Kemenkes Rl, 2018). Stunting can be caused by several factors such as the nutritional status of the mother during pregnancy, a long history of birth, a history of LBW, a history of breastfeeding, a history of complementary breastfeeding, the mother's height, the number of families, the economic status, the level of education, the occupation of parents and parenting styles (Kusuma , 2013; Nurkomala, 2017).

Given the dangers of stunting, preventing stunting can be done through government interventions such as nutrition-related education, childcare education, and supplementary feeding for pregnant women to overcome KEK and anemia. It can also be done by managing malnutrition, immunization, access to clean water, providing National Health Insurance (TNP2K, 2017)

\section{MATERIALS AND METHODS}

This research is a quantitative study with a case control design. The population in this study was that there were 205 stunted children aged 2459 months in the Kasreman Health Center working area, the sample technique was purposive sampling using inclusion criteria for the case sample, namely mothers who had stunted children aged 24-59 months and lived in Kasreman 
district registered in the KIA register, and willing to become respondents by signing the informant, while for the control sample, mothers who have children aged 24-59 months, reside in Kasreman sub-district, are recorded in the KIA register, and are willing to become respondents by signing the informant. This study uses primary data, namely by filling out a questionnaire and taking measurements using microtoas. The dependent variable in this study was stunting, the independent variables were the nutritional status of pregnant women, body length of birth, history of LBW, history of breastfeeding, history of complementary feeding, height of mothers, number of families, economic status, education level, occupation of parents.

\section{RESULTS}

Table 1 The relationship (maternal nutritional status) of KEK mothers with the incidence of stunting

\begin{tabular}{|c|c|c|c|c|c|c|c|c|}
\hline \multirow{3}{*}{$\begin{array}{l}\text { Upper Arm } \\
\text { Circumference }\end{array}$} & \multicolumn{4}{|c|}{ Stunting } & \multirow{2}{*}{\multicolumn{2}{|c|}{ TOTAL }} & \multirow{3}{*}{ OR } & \multirow{3}{*}{ P Value } \\
\hline & \multicolumn{2}{|c|}{ Stunting } & \multicolumn{2}{|c|}{ Normal } & & & & \\
\hline & $\mathbf{N}$ & $\%$ & $\mathbf{N}$ & $\%$ & total & $\%$ & & \\
\hline $\begin{array}{c}\text { Chronic lack of } \\
\text { energy }<23,5 \mathrm{~cm}\end{array}$ & 19 & 50,0 & 14 & 36,8 & 33 & 43,4 & 1,714 & 0,355 \\
\hline Normal 23,5 cm & 19 & 50,0 & 24 & 63,4 & 43 & 56,6 & & \\
\hline Total & 38 & 100.0 & 38 & 100.0 & 76 & 100.0 & & \\
\hline
\end{tabular}

In table 1 above it can be seen that between chronic lack of energy mothers and normal mothers have the same number, namely 19 respondents $(50,0 \%)$ and have stunted children, but the chi square analysis results show a $p$ value of 0.355 ( $p>0.05$ ) which means There is no relationship between chronic lack of energy mothers and the incidence of stunting, the OR value says that mothers with chronic lack of energy have a risk of 1.714 more at risk of having stunted children than normal mothers.

Table $\mathbf{2}$ The relationship between anemia and the incidence of stunting

\begin{tabular}{|c|c|c|c|c|c|c|c|c|}
\hline \multirow{3}{*}{ Hemoglobin } & \multicolumn{4}{|c|}{ Stunting } & \multirow{2}{*}{\multicolumn{2}{|c|}{ TOTAL }} & \multirow{3}{*}{ OR } & \multirow{3}{*}{ P Value } \\
\hline & \multicolumn{2}{|c|}{ Stunting } & \multicolumn{2}{|c|}{ Normal } & & & & \\
\hline & $\mathbf{N}$ & $\%$ & $\mathbf{N}$ & $\%$ & total & $\%$ & & \\
\hline Anemia $11 \mathrm{~g} / \mathrm{dL}$ & 15 & 39,5 & 5 & 13,2 & 20 & 26,3 & 4,304 & 0,019 \\
\hline Normal > $11 \mathrm{~g} / \mathrm{dL}$ & 23 & 60,5 & 33 & 86,8 & 56 & 73,7 & & \\
\hline Total & 38 & 100.0 & 38 & 100.0 & 76 & 100.0 & & \\
\hline
\end{tabular}

The table above shows the different results between anemia mothers 15 respondents (39.5\%) and normal mothers 23 respondents (60.5\%), but the analysis results show that anemia mothers have a relationship with the incidence of stunting with a $p$-value of $0.019(p<0.05)$. The OR results said that 4.304 anemic mothers were more at risk of giving birth to stunting children than normal mothers / had HB levels $>11 \mathrm{~g} / \mathrm{dL}$.

Table 3 Relationship between body length at birth and the incidence of stunting

\begin{tabular}{|c|c|c|c|c|c|c|c|c|}
\hline \multirow{3}{*}{ Birth Length } & \multicolumn{4}{|c|}{ Stunting } & \multirow{2}{*}{\multicolumn{2}{|c|}{ TOTAL }} & \multirow{3}{*}{ OR } & \multirow{3}{*}{ P Value } \\
\hline & \multicolumn{2}{|c|}{ Stunting } & \multicolumn{2}{|c|}{ Normal } & & & & \\
\hline & $\mathbf{N}$ & $\%$ & $\mathbf{N}$ & $\%$ & total & $\%$ & & \\
\hline Short $<48 \mathrm{~cm}$ & 14 & 36,8 & 11 & 28,9 & 25 & 32,9 & 1,472 & 0,625 \\
\hline Normal $23 \mathrm{~cm}$ & 24 & 63,2 & 27 & 71,2 & 51 & 67,1 & & \\
\hline Total & 38 & 100.0 & 38 & 100.0 & 76 & 100.0 & & \\
\hline
\end{tabular}

In table 3, there are different results for children born short 14 respondents (36.8\%) and children born with normal length as many as 24 respondents $(63.2 \%)$, chi square analysis results show the value of $p=0.625(p>$ $0,05)$ which means that there is no relationship between birth length and the incidence of stunting, but the 
OR results say that children who have a short birth history are 1,472 times at risk of stunting than children born with normal length.

Table 4 The relationship between low birth weight (LBW) and the incidence of stunting

\begin{tabular}{|c|c|c|c|c|c|c|c|c|}
\hline \multirow{3}{*}{ Birth Length } & \multicolumn{4}{|c|}{ Stunting } & \multirow{2}{*}{\multicolumn{2}{|c|}{ TOTAL }} & \multirow{3}{*}{ OR } & \multirow{3}{*}{ P Value } \\
\hline & \multicolumn{2}{|c|}{ Stunting } & \multicolumn{2}{|c|}{ Normal } & & & & \\
\hline & $\mathbf{N}$ & $\%$ & $\mathbf{N}$ & $\%$ & total & $\%$ & & \\
\hline $\begin{array}{l}\text { Low Birth Weight } \\
<2500 \text { Gram }\end{array}$ & 9 & 23,7 & 4 & 10,5 & 13 & 17,1 & 2,638 & 0,223 \\
\hline Normal $2500 \mathrm{~g}$ & 29 & 76,3 & 34 & 89,5 & 63 & 82,9 & & \\
\hline Total & 38 & 100.0 & 38 & 100.0 & 76 & 100.0 & & \\
\hline
\end{tabular}

In table 4, it can be seen that 9 respondents (23.7\%) and 29 respondents (76.3\%) have experienced stunted LBW history, and the results of $p$ value $0.233(p>0.05)$ indicate that there is no relationship between LBW. with stunting, even though there was no association between children with a history of LBW, they had a risk of 2,638 times than children with a history of LBW.

Table 5 History of the length of breastfeeding with the incidence of stunting

\begin{tabular}{|c|c|c|c|c|c|c|c|c|}
\hline \multirow{3}{*}{ Breastfeeding } & \multicolumn{4}{|c|}{ Stunting } & \multirow{2}{*}{\multicolumn{2}{|c|}{ TOTAL }} & \multirow{3}{*}{ OR } & \multirow{3}{*}{ P Value } \\
\hline & \multicolumn{2}{|c|}{ Stunting } & \multicolumn{2}{|c|}{ Normal } & & & & \\
\hline & $\mathbf{N}$ & $\%$ & $\mathbf{N}$ & $\%$ & total & $\%$ & & \\
\hline$<6$ Month & 8 & 21,1 & 6 & 15,8 & 14 & 18,4 & 1,422 & 0,767 \\
\hline$>6$ Month & 30 & 78,9 & 32 & 84,2 & 62 & 81,6 & & \\
\hline Total & 38 & 100.0 & 38 & 100.0 & 76 & 100.0 & & \\
\hline
\end{tabular}

In the table above, children who were breastfed for $<6$ months were 8 respondents (21.1\%) and for giving $>6$ months were 30 respondents (78.9\%) and it showed that there was no relationship between breastfeeding and the incidence of stunting based on the $p$-value. $0.767(p>0.05)$ and the OR results showed that children who had a history of breastfeeding $<6$ months had a 1.442 times risk of stunting than children who had a history of breastfeeding up to $>6$ months of age.

Table 6 History of complementary feeding with stunting

\begin{tabular}{|c|c|c|c|c|c|c|c|c|}
\hline \multirow{3}{*}{$\begin{array}{c}\text { Complementary } \\
\text { Foods of } \\
\text { Breastmilk } \\
\end{array}$} & \multicolumn{4}{|c|}{ Stunting } & \multirow{2}{*}{\multicolumn{2}{|c|}{ TOTAL }} & \multirow{3}{*}{ OR } & \multirow{3}{*}{ P Value } \\
\hline & \multicolumn{2}{|c|}{ Stunting } & \multicolumn{2}{|c|}{ Normal } & & & & \\
\hline & $\mathbf{N}$ & $\%$ & $\mathbf{N}$ & $\%$ & total & $\%$ & & \\
\hline Early $<6$ Month & 9 & 23,7 & 7 & 18,4 & 16 & 21,1 & 1,374 & 0,778 \\
\hline Normal > 6 Month & 29 & 76,3 & 31 & 81,6 & 60 & 78,9 & & \\
\hline Total & 38 & 100.0 & 38 & 100.0 & 76 & 100.0 & & \\
\hline
\end{tabular}

In the table above, children who have a history of early complementary breastfeeding are 9 people (23.7\%) and 29 people (76.3\%) have normal complementary breastfeeding, but both have children who are stunted, from the analysis results obtained a $p$-value of 0.778 ( $p>0.05$ ) with OR said that children who were given early complementary breastfeeding were 1,474 times more likely to become stunted children than children who were given normal complementary breastfeeding ( $>6$ months). 
Table 7 Relationship between maternal height and the incidence of stunting.

\begin{tabular}{|c|c|c|c|c|c|c|c|c|}
\hline \multirow{3}{*}{$\begin{array}{c}\text { Height of } \\
\text { Pregnant Women }\end{array}$} & \multicolumn{4}{|c|}{ Stunting } & \multirow{2}{*}{\multicolumn{2}{|c|}{ TOTAL }} & \multirow{3}{*}{ OR } & \multirow{3}{*}{ P Value } \\
\hline & \multicolumn{2}{|c|}{ Stunting } & \multicolumn{2}{|c|}{ Normal } & & & & \\
\hline & $\mathbf{N}$ & $\%$ & $\mathbf{N}$ & $\%$ & total & $\%$ & & \\
\hline Short $<150 \mathrm{~cm}$ & 16 & 42,1 & 11 & 28,9 & 27 & 35,5 & 1,785 & 0,338 \\
\hline High $>150 \mathrm{~cm}$ & 22 & 57,9 & 27 & 71,1 & 49 & 64,5 & & \\
\hline Total & 38 & 100.0 & 38 & 100.0 & 76 & 100.0 & & \\
\hline
\end{tabular}

In the stunting table, there were 16 respondents (42.1\%) with a height $<150 \mathrm{~cm}$ and 22 respondents (57.9\%) who had a height $>150 \mathrm{~cm}$, but the chi square analysis showed that there was no relationship between maternal height and incidence. stunting seen from the $p$-value $0.338(p>0.05)$. The $0 R$ results showed that mothers who were short $(<150 \mathrm{~cm}) 1,785$ at risk of giving birth to stunted children than mothers who were tall $(>150 \mathrm{~cm})$.

Table 8 The relationship between the number of families and the incidence of stunting

\begin{tabular}{|c|c|c|c|c|c|c|c|c|}
\hline \multirow{3}{*}{$\begin{array}{l}\text { Number of } \\
\text { Family Members }\end{array}$} & \multicolumn{4}{|c|}{ Stunting } & \multirow{2}{*}{\multicolumn{2}{|c|}{ TOTAL }} & \multirow{3}{*}{ OR } & \multirow{3}{*}{ P Value } \\
\hline & \multicolumn{2}{|c|}{ Stunting } & \multicolumn{2}{|c|}{ Normal } & & & & \\
\hline & $\mathbf{N}$ & $\%$ & $\mathbf{N}$ & $\%$ & total & $\%$ & & \\
\hline Small $<4$ & 30 & 78,9 & 28 & 73,7 & 58 & 76,3 & 1,339 & 0,787 \\
\hline Big $>4$ & 8 & 21,1 & 10 & 26,3 & 18 & 23,7 & & \\
\hline Total & 38 & 100.0 & 38 & 100.0 & 76 & 100.0 & & \\
\hline
\end{tabular}

In the table above, it can be seen in the stunting column, the number of small families was 30 respondents (78.9) while the large families were 8 respondents $(21.1 \%)$ from the results of the analysis carried out the $p$ value was 0.787 ( $p>0.05$ ) which means that there is no relationship between the number of families and the incidence of stunting. However, families that have a small number of family members are 1,339 times more likely to have stunted children than a large family.

Table 9 The relationship between economic status and the incidence of stunting

\begin{tabular}{|c|c|c|c|c|c|c|c|c|}
\hline \multirow{3}{*}{ Economic Status } & \multicolumn{4}{|c|}{ Stunting } & \multirow{2}{*}{\multicolumn{2}{|c|}{ TOTAL }} & \multirow{3}{*}{ OR } & \multirow{3}{*}{ PValue } \\
\hline & \multicolumn{2}{|c|}{ Stunting } & \multicolumn{2}{|c|}{ Normal } & & & & \\
\hline & $\mathbf{N}$ & $\%$ & $\mathbf{N}$ & $\%$ & total & $\%$ & & \\
\hline Small & 28 & 73,7 & 32 & 84,2 & 60 & 78,9 & 0,525 & 0,399 \\
\hline Big & 10 & 26,3 & 6 & 15,8 & 16 & 21,1 & & \\
\hline Total & 38 & 100.0 & 38 & 100.0 & 76 & 100.0 & & \\
\hline
\end{tabular}

In the table above, families with small and large income both have children who are stunted, from families with low income there are 28 respondents (73.7\%) and from families with large income as many as 10 respondents (26.3\%). Judging from the OR results, families with low income are indeed at risk of having children with stunting 0.525 times compared to families with large income. 
Table 10 The relationship between parental education (father) and the incidence of stunting

\begin{tabular}{|c|c|c|c|c|c|c|c|c|}
\hline \multirow{3}{*}{$\begin{array}{l}\text { Father's } \\
\text { Education }\end{array}$} & \multicolumn{4}{|c|}{ Stunting } & \multirow{2}{*}{\multicolumn{2}{|c|}{ TOTAL }} & \multirow{3}{*}{ OR } & \multirow{3}{*}{ P Value } \\
\hline & \multicolumn{2}{|c|}{ Stunting } & \multicolumn{2}{|c|}{ Normal } & & & & \\
\hline & $\mathbf{N}$ & $\%$ & $\mathbf{N}$ & $\%$ & total & $\%$ & & \\
\hline Low & 30 & 78,9 & 27 & 71.1 & 57 & 75,0 & 1,528 & 0,596 \\
\hline High & 8 & 21,1 & 11 & 28,9 & 19 & 25,01 & & \\
\hline Total & 38 & 100.0 & 38 & 100.0 & 76 & 100.0 & & \\
\hline
\end{tabular}

Judging from the low education of the father, as many as 30 respondents (78.9\%) were stunted and 8 respondents (26.3\%) also had children who were stunted, based on the $p$-value $0.596(p>0.05)$ or it means that there is no relationship between father's education and the incidence of stunting, OR shows that fathers with low education are 1.528 times more likely to have stunted children than fathers with high education.

Table 11 The relationship between parental education (mother) and the incidence of stunting

\begin{tabular}{|c|c|c|c|c|c|c|c|c|}
\hline \multirow{3}{*}{$\begin{array}{l}\text { Mother's } \\
\text { Education }\end{array}$} & \multicolumn{4}{|c|}{ Stunting } & \multirow{2}{*}{\multicolumn{2}{|c|}{ TOTAL }} & \multirow{3}{*}{ OR } & \multirow{3}{*}{ PValue } \\
\hline & \multicolumn{2}{|c|}{ Stunting } & \multicolumn{2}{|c|}{ Normal } & & & & \\
\hline & $\mathbf{N}$ & $\%$ & $\mathbf{N}$ & $\%$ & total & $\%$ & & \\
\hline Low & 7 & 18,4 & 14 & 36,8 & 21 & 27,6 & 0,387 & 0,124 \\
\hline High & 31 & 81,6 & 24 & 63,2 & 55 & 72,4 & & \\
\hline Total & 38 & 100.0 & 38 & 100.0 & 76 & 100.0 & & \\
\hline
\end{tabular}

In the table of maternal education, there is a big difference between mothers with low education, 7 respondents $(18.4 \%)$, while for mothers with high education, 31 respondents $(81.6 \%)$, the same as father's education, the results of the analysis show a p-value of $0.124(p>0.05)$ stated that there was no relationship between maternal education and the incidence of stunting. Mothers with low education are 0.387 times more likely to have a stunted child than mothers with high education.

Table 12 The relationship between the work of parents (father) and the incidence of stunting.

\begin{tabular}{|c|c|c|c|c|c|c|c|c|}
\hline \multirow{3}{*}{ Father's Job } & \multicolumn{4}{|c|}{ Stunting } & \multirow{2}{*}{\multicolumn{2}{|c|}{ TOTAL }} & \multirow{3}{*}{ OR } & \multirow{3}{*}{ P Value } \\
\hline & \multicolumn{2}{|c|}{ Stunting } & \multicolumn{2}{|c|}{ Normal } & & & & \\
\hline & $\mathbf{N}$ & $\%$ & $\mathbf{N}$ & $\%$ & total & $\%$ & & \\
\hline Odd jobs & 30 & 78,9 & 27 & 71,1 & 57 & 75,0 & 1,528 & 0,596 \\
\hline $\begin{array}{l}\text { Permanent } \\
\text { employee }\end{array}$ & 8 & 21,1 & 11 & 28,9 & 19 & 25,0 & & \\
\hline Total & 38 & 100.0 & 38 & 100.0 & 76 & 100.0 & & \\
\hline
\end{tabular}

In the table, there are 30 respondents (78.9\%) of fathers who work odd jobs have stunted children, and a number of 8 respondents (21.1\%) fathers who work as permanent also have stunted children. Based on the pvalue of 0.596 ( $p>0.05$ ), which means that the work of parents (father) has no relationship with the incidence of stunting. Even though it does not have a significant relationship, fathers who are odd jobs are 1.528 times more likely to have a stunted child than fathers who work as permanent employees. 
Table 13 The relationship between the work of parents (mother) and the incidence of stunting.

\begin{tabular}{|c|c|c|c|c|c|c|c|c|}
\hline \multirow{3}{*}{ Mother's Job } & \multicolumn{4}{|c|}{ Stunting } & \multirow{2}{*}{\multicolumn{2}{|c|}{ TOTAL }} & \multirow{3}{*}{ OR } & \multirow{3}{*}{ P Value } \\
\hline & \multicolumn{2}{|c|}{ Stunting } & \multicolumn{2}{|c|}{ Normal } & & & & \\
\hline & $\mathbf{N}$ & $\%$ & $\mathbf{N}$ & $\%$ & total & $\%$ & & \\
\hline Odd jobs & 35 & 92,1 & 35 & 92,5 & 70 & 92,1 & 1,000 & 1,000 \\
\hline $\begin{array}{l}\text { Permanent } \\
\text { employee }\end{array}$ & 3 & 7,9 & 3 & 7,92 & 6 & 7,9 & & \\
\hline Total & 38 & 100.0 & 38 & 100.0 & 76 & 100.0 & & \\
\hline
\end{tabular}

The stunting table shows the number of mothers who work odd jobs as many as 35 respondents $(92.1 \%)$ and mothers who are permanent employees are 3 respondents $(7.9 \%)$. The $p$-value shows $p 1,000(p>0.05)$ which means that there is no relationship between maternal work and the incidence of stunting. From the OR results, mothers who work odd jobs are 1,000 times more likely to have a stunted child than mothers who work as permanent employees.

Table 14 The relationship between the work of parents (mother) and the incidence of stunting.

\begin{tabular}{|c|c|c|c|c|c|c|c|c|}
\hline \multirow{3}{*}{ Mother's Job } & \multicolumn{4}{|c|}{ Stunting } & \multirow{2}{*}{\multicolumn{2}{|c|}{ TOTAL }} & \multirow{3}{*}{ OR } & \multirow{3}{*}{ PValue } \\
\hline & \multicolumn{2}{|c|}{ Stunting } & \multicolumn{2}{|c|}{ Normal } & & & & \\
\hline & $\mathbf{N}$ & $\%$ & $\mathbf{N}$ & $\%$ & total & $\%$ & & \\
\hline Bad & 8 & 21,1 & 17 & 44,7 & 25 & 32,9 & 1,329 & 0,051 \\
\hline Good & 30 & 78,9 & 21 & 55,3 & 51 & 67,1 & & \\
\hline Total & 38 & 100.0 & 38 & 100.0 & 76 & 100.0 & & \\
\hline
\end{tabular}

In the parenting table above, families who have bad parenting are 8 respondents (21.1\%) and good parenting styles are 30 respondents (78.9\%) with a p-value of $0.051(p>.05)$ which says that there is no relationship between family parenting and the incidence of stunting, but families with poor parenting are still 1.329 times more likely to have stunted children than families with good parenting.

\section{DISCUSSION}

In this study said that there was no relationship between women in KEK and the incidence of stunting. This study is not in accordance with research (Sukmawati et al., 2018) which states that there is a relationship between KEK mothers and the incidence of stunting in Makassar with a result of $P=0.01$ ( $p<0.05$ ). According to Sukmawati, a mother who experiences Chronic Energy Deficiency (KEK) means that the mother has been experiencing a state of malnutrition for a long time, if this condition occurs then the nutritional needs for the fetal growth and development process will be hampered so that the mother is at risk of giving birth to LBW babies. Children born with LBW conditions are more at risk of experiencing stunting. However, according to researchers, mothers who experience KEK will pay more attention in consuming the food that will be given to children who are still in their womb, because the mother realizes that she is undernourished with a thin body condition, the mother will try to fulfill the nutrition, this is supported by (Syafa ' ah, 2016).

\section{Relationship between (HB) and stunting.}

Meanwhile, in table 2, the statistical test results show that anemia has a relationship with the incidence of stunting. Research on HB levels is in accordance with research conducted by (Widyaningrum and Romadhon, 2018) which states that there is a relationship between $\mathrm{HB}$ levels and stunting in Madiun with statistical test results $p=0.005(p<0.05)$. The history of anemia in pregnant women is still high. In this incident it was caused by a lack of nutritional status and insufficient energy intake. One of the most prevalent health problems that occur during pregnancy is an $\mathrm{Hb}$ level of less than $11 \mathrm{~g} / \mathrm{dl}$, which indicates that pregnant women suffer from anemia. Anemia in pregnant women increases the risk of having a Low Birth Weight Baby (LBW), short birth length or stunting, the risk of bleeding before and during delivery can even cause death to the 
mother and the baby if the mother is suffering from severe anemia. According to the theory above, the researchers conclude that the condition of pregnant women with anemia who have HB levels $<11 \mathrm{~g} / \mathrm{dL}$ will affect the supply of nutrients from mother to baby, this is because anemia in pregnant women will cause a decrease in blood volume which in a long time will have an impact on the shrinking of the placenta. this is supported by Yanistin's research (2017) in Gunung Kidul. Table 3 shows that there is no relationship between body length at birth and the incidence of stunting. In contrast to research (Sutrio and Lupianan, 2019) which states that there is a relationship between body length at birth and the incidence of stunting in Lampung with statistical test results $p=0.00(p<0.05)$. This theory explains that children who are stunted from the beginning, that is, before the age of six months, will experience more severe stunting by the age of two. However, the researchers argue that even though children born short do not affect stunting if the nutrition is given good attention during the first six months of the child or often referred to as chasing growth, on the other hand, children who are born normally can also experience stunting if during their growth period nutritional fulfillment is not fulfilled, this is supported by Lyana (2018) in Sukajadi.

\section{The relationship between LBW and stunting}

Table 4 states that there is no relationship between LBW and the incidence of stunting. This is supported by research (Aini, Nugraheni and Pradigdo, 2018) which shows there is no relationship between LBW and the incidence of stunting in Cepu, the results of statistical tests in this study are $p=0.223$ ( $p>0.05)$. In the first 6 months, if the mother of the toddler can catch up to grow, there is a chance that the toddler can grow to a normal height and avoid stunting at a later age. Researchers agree with Elsa's opinion that during that time LBW babies have sufficient time and opportunity to grow and develop. This is supported by the existence of various intervention programs to increase LBW from the government as well as better public awareness in dealing with the problem of underweight in children, this is supported by research conducted by President (2019) at Oepoi.

\section{The relationship between breastfeeding and stunting}

In this study it can be seen that there is no relationship between breastfeeding and the incidence of stunting with the test result of $p=$ $0.767(p>0.05)$. This is in line with research (Ibrahim et al., 2019) which states that there is no relationship between breastfeeding and stunting in Enkerang district with a statistical test result value of $p=0.180 \quad(p>0.05)$. Exclusive breastfeeding has no relationship with the incidence of stunting in children aged 0-59 months. This happens because most mothers of children under five give exclusive breastfeeding, but their children are stunted. Stunting is influenced by several factors other than breast milk such as infectious diseases, such as diarrhea and Acute Respiratory Infection (ARI), this is supported by Pengan's research (2019).

\section{Relationship history of solids with stunting}

In table 6, it can be seen that there is no relationship between solids and the incidence of stunting with the resulting $p$ value $=0.778(p>$ 0.05 ). This is not in line with research conducted by (Fitri, 2018) which states that there is a relationship between complementary foods and the incidence of stunting in Sidomulyo with a value of $p=0.001$ $(p<0.05)$. According to the theory of breastfeeding too early by mothers of toddlers because of the cessation of exclusive breastfeeding and the perception that arises from the mother that breastfeeding is not enough and the milk does not come out smoothly so the child is fussy. Finally, the mother provides additional food to the child.

Researchers agree with the above theory because giving complementary foods too early increases the risk of infectious diseases such as diarrhea because complementary foods are not as clean and easy to digest as breast milk. Diarrhea is associated with failure to thrive due to malabsorption of nutrients during diarrhea. Apart from giving complementary foods too early, the delay in giving complementary foods also causes the growth and development of toddlers to be hampered because the needs of toddlers are not fulfilled, in this study most mothers gave complementary foods when the child was six months old but was still stunted This happens because in the provision of complementary foods, mothers tend to provide food that their children want regardless of the nutrition in it, as well as the frequency of eating irregularly, this opinion is supported by Andi (2019).

\section{The relationship between maternal height and stunting}

In this study it was said that there was no relationship between maternal height and the incidence of stunting with the results of the statistical test $p=0.338(p>0.05)$, this research is in line with research (Mokodimpit, Kapantow and Mayulu, 2018) in Minahasa with test results. $p$ value $=0.406(p>0.05)$ which indicates there is no 
relationship between maternal height and the incidence of stunting. Slow growth in toddlers can be caused by various things, including disease, lack of nutritional intake, bad environment, and indications of genetic factors from parents. According to researchers, if parents are short due to nutritional deficiencies or diseases that are not due to genes, it is possible that the child will grow to a normal height as long as the child is not exposed to other risk factors. Other factors referred to include disease, lack of nutritional intake, bad environment, and indications of genetic factors from parents, opinions are supported by research conducted by Enjelina (2018).

\section{The relationship between the number of families and stunting}

In table 8 there is a statistical test result, the value of $p=0.589$ ( $p>0.05)$, which means that there is no relationship between the number of families and the incidence of stunting. This is also supported by research (Angelina, Perdana and Humairoh, 2018) in Lampung with a statistical test result of $p=0.197(p>0.05)$. The factor of unfair distribution of food can also result in the toddler getting an insufficient amount of food, so that his nutritional intake is lacking. Researchers also argue that toddlers who have a smaller number of siblings are not necessarily free from stunting. Because it could be that the factor of unfair distribution of food, as mentioned by Christin, can also result in the toddler getting an insufficient amount of food, so that his nutritional intake is lacking. Incorrect family parenting such as accustoming older children to more food or nutritional intake than younger children (toddlers) can also be one of the factors that influence the high incidence of stunting among toddlers who come from small families. In this study it can be seen that families with a number of $<4$ people are more likely to experience stunting, this is supported by Irvani (2018) in Enkerang.

\section{Economic status with the incidence of stunting}

In table 9, you can see the results of the statistical test $p=0.339(p>0.05)$ which indicates that there is a relationship between economic status and the incidence of stunting. This research is supported by research conducted (Dakhi, 2018) in Jati Makmur with the results of statistical tests showing the value of $p=0.891$ ( $p>0.05)$, which means there is no relationship between economic status and stunting. Alwin said high income families are not fully spent on basic food needs, but for other needs. A high income level does not necessarily guarantee a good nutritional status for children under five, because the income level is not necessarily allocated enough for food needs. In this research, people with low income can also meet their food needs by growing their own food items such as vegetables on their own land. However, a high increase in income will increase the opportunity to choose food ingredients and increase consumption that is more nutritious. This is supported by Sri's (2019) research in Minahasa.

\section{The relationship between parental education and stunting}

This study shows that there is no relationship between parental education, both mother and father, and the incidence of stunting. This is in accordance with research (Venuz et al., 2019) in Oepoi which said that there was no relationship between parental education and stunting.In his research, the results of the father's education statistical test were $p=0.596(p>0.05)$ and the results of the analysis of maternal education. $p=0.124$ ( $p>0.05)$. Mothers who have a higher education level have children under five with greater stunting problems than mothers with less knowledge. A high level of maternal education does not guarantee having children under five with normal nutritional status. Mothers who have good knowledge are expected to be able to apply the knowledge they have in everyday life. However, not only is the behavior influenced by the level of education, it is also influenced by other factors, for example socio-economic, sociocultural, and environmental. From this research it can be interpreted that parents with low education do not necessarily have knowledge of nutrition. Parents with low education are diligent in attending posyandu, especially mothers and following nutrition counseling for toddlers so that they get sufficient knowledge and are able to care for their children properly. This can be seen from the arrival of mothers to the posyandu every month in the KMS book. The more often mothers go to posyandu, the more knowledge they get about nutrition, this opinion is supported by Elsa's research (2018) in Cepu.

\section{The relationship between parents' work and stunting}

Parents' occupation has no relationship with the incidence of stunting. This research is not in line with research (Ika and Ariati, 2019) in Panduman which states that there is a relationship between parental work and the incidence of stunting. The main factor determining the quality and quantity of food needs is work related to income in the family which is able to meet the 
needs of all families and is related to the economic status of the family. However, in this study, there was no relationship between parental work and the incidence of stunting due to the application of parenting patterns. Poor parenting style is also not always caused by the work status of the parents, but can be caused by other factors such as lack of parental knowledge about nutrition. Parents who only work odd jobs or even don't work do not always have children who are stunted because in fulfilling their children's nutrition the parents will try their best, in this study supported by Elsa (2018) in Cepu.

\section{The relationship between parenting and stunting}

In table 12 it can be seen from the results of the statistical test $p=0.051$ ( $p>0.05)$, these results indicate that there is no relationship between parenting styles and the incidence of stunting. This is in line with research (Agustina and Hamisah, 2019) in Aceh which states that there is no relationship between parenting styles and the incidence of stunting with the results of the statistical test $p=0.189$ ( $p>0.05)$. Parenting patterns in feeding have a role in the degree of stunting because food intake is fully regulated by parents, especially mothers, but in this study most respondents have good parenting styles, although in good parenting patterns, stunting can occur due to other factors such as: the economy does not support This good parenting style so that there are still many children who get good parenting experience stunting, knowledge in providing good nutrition also plays an important role in the occurrence of stunting, this is in line with Sofa (2019).

\section{CONCLUSION}

In the Kasreman Health Center working area from several factors studied in the bivariate analysis it was found that anemic mothers with HB $<11 \mathrm{~g} / \mathrm{dL}$ had a relationship with the incidence of stunting indicated by a $p$-vlaue value of $0.019(p=$ 0.05).

\section{REFERENCES}

Agustina and Hamisah, I. (2019) 'Hubungan Pemberian Asi Ekslusif, Berat Bayi Lahir Dan Pola Asuh Dengan Kejadian Stunting Di Wilayah Kerja Puskesmas Reubee Kabupaten Pidie', Journal Of Healthcare Technology and Medicine, 5(2), pp. 162170.

Aini, E. N., Nugraheni, S. A. and Pradigdo, S. F. (2018) 'Faktor yang mempengaruhi stunting pada Balita Usia 24-59 Bulan di
Puskesmas CEPU Kabupaten Blora', Jurnal Kesehatan Masyarakat, 6(5), pp. 454-461.

Angelina, C., Perdana, agung aji and Humairoh (2018) 'faktor kejadian stunting balita usia 6-23 bulan di provinsi lampung', 7(3), pp. 127-134.

Dakhi, A. (2018) 'Hubungan Pendapatan Keluarga, Pendidikan, Dan Pengetahuan Ibu Tentang Gizi Dengan Kejadian Stunting Pada Anak Umur 6-23 Bulan Di Wilayah Kerja Puskesmas Jati Makmur Binjai Utara'.

Fitri, L. (2018) 'Hubungan Bblr Dan Asi Ekslusif Dengan Kejadina Stunting Di Puskesmas Lima Puluh Pekanbaru', Jurnal Endurance, 3(1), pp. 131-137.

Ibrahim, I. A. et al. (2019) 'Analisis Determinan Kejadian Growth Failure ( Stunting) Pada Anak Balita Usia 12-36 Bulan Di Wilayah Pegunungan Desa Bontongan Kecamatan Baraka Kabupaten Enrekang', Public Health science Journal, 11(1), pp. 50-64. Available at: http://journal.uinalauddin.ac.id/index.php/AlSihah/article/view/9418.

Ika, L. and Ariati, P. (2019) 'Faktor-Faktor Resiko Penyebab Terjadinya Stunting Pada Balita Usia 23-59 Bulan Risk Factors Causes Of Stunting In Toddlers Aged 23-59 Months', $\mathrm{VI}(1)$, pp. 28-37.

llahi, rizky kurnia (2017) 'Hubungan Pendapatan Keluarga, Berat Lahir, Dan Panjang Lahir Dengan Kejadian', Jurnal Manajemen Kesehatan, 3(1), pp. 1-14.

Kemenkes RI (2018) 'Hasil Utama Riskesdas 2018', pp. 11-12.

Kementerian PPN/ Bappenas (2018) Pedoman Pelaksanaan Intervensi Penurunan Stunting Terintegrasi Di Kabupaten/Kota, Rencana Aksi Nasional Dalam Rangka Penurunan Stunting: Rembuk Stunting. Available at: https://www.bappenas.go.id.

Kusuma, K. E. (2013) 'Faktor Risiko Kejadian Stunting pada Anak Usia 2-3 Tahun (Studi di Kecamatan Semarang Timur )', pp. 2530. Available at: http://eprints.undip.ac.id/41856/ .

Mokodimpit, E. P., Kapantow, N. H. and Mayulu, N. (2018) 'Hubungan Antara Tinggi Badan Orang Tua Dengan Kejadian Stunting Pada Anak Usia 24-59 Bulan Di Wilayah Kerja Puskesmas Pusomaen Kabupaten Minahasa Tenggara', jurnal KESMES, 7(5), pp. 4-5. Available at: https://ejournal.unsrat.ac.id/index.php/k esmas/article/view/22421 . 
Nurkomala, S. (2017) 'Praktik Pemberian Mpasi (Makanan Pendamping Air Susu Ibu) Pada Anak Stunting Dan Tidak Stunting Usia 624 Bulan', Journal of Nutrition College, 7(2), p. 45. doi: 10.14710/jnc.v7i2.20822.

Sukmawati et al. (2018) 'Status Gizi Ibu Saat Hamil , Berat Badan Lahir Bayi Dengan Stunting Pada Balita', 25.

Sutrio and Lupianan, M. (2019) 'Berat Badan dan Panjang Badan Lahir Meningkatkan Kejadian Stunting', Jurnal Gizi, 12(1), pp. 21-29.
Syafa'ah, H. (2016) 'Hubungan Status Gizi dan Asupan Gizi Ibu Hamil Trimester III dengan Panjang Bayi Lahir di Puskesmas Bendosari Kabupaten Sukoharjo', pp. 7-9.

TNP2K (2017) 100 Kabupaten Prioritas Untuk Intervensi Anak Kerdil.

Venuz, P. et al. (2019) 'Analisis Faktor Risiko Kejadian Stunting Pada Balita', Cendana Medical Journal, 17(3).

WHO (2018) world health statistic.

Widyaningrum, D. A. and Romadhon, D. A. (2018) 'Riwayat Anemia Kehamilan Dengan Kejadian Stunting Pada Balita Di Desa Ketandan Dagangan Madiun', 10(2). 